\title{
DFT Study and Synthesis of New 1, 2, 3-triazoles Obtained by 1, 3-Dipolar Cycloaddition Derived from 5-chloro-1-(prop-2-yn-1-yl)indoline-2, 3-dione
}

\author{
Z. Tribak ${ }^{1}$, M. K. Skalli ${ }^{1}$, O. Senhajii ${ }^{2}$, Y. Kandri Rodi ${ }^{3}$ \\ ${ }^{1}$ Laboratory of Applied Chemistry, Sidi Mohamed Ben Abdellah University, Faculty of Science and Technology, BP 2202, Fez, Morocco \\ ${ }^{2}$ Laboratory of Applied Physical Chemistry, Moulay Ismaïl University, Faculty of Sciences and Technology of Errachidia, Morocco \\ ${ }^{3}$ Laboratory of Applied Organic Chemistry, Faculty of Science and Technology, BP 2202, Fez, Morocco
}

\begin{abstract}
We report in this paper the reaction of 1, 3-Dipolar Cycloaddition between azides and 5-chloro-1-(prop-2-yn-1-yl)indoline-2, 3-dione in order to synthesize new cycloadducts. The configuration of the products obtained was determined by the magnetic resonance of the proton and carbon. A theoretical study was also carried out, based on the DFT-B3LYP calculation method. The results are in agreement with experimental regiochemistry.
\end{abstract}

Keywords: 5-chloro-1-(prop-2-yn-1-yl)indoline-2, 3-dione, dipolarophile, 1, 3-Dipolar Cycloaddition, theoretical study, DFT

\section{Introduction}

The Heterocyclic compounds play an important role in medicinal chemistry to understand the biological functioning at the molecular level and also the development of the interest of new biologically active products which are used as remedies for many diseases [1-2]. Thus, it seemed interesting to us to exploit the 1,3-dipolar cycloaddition reactions which make it possible to provide a wide range of biologically and pharmacologically active heterocyclic products [3-8]. The 1, 3-dipolar cycloaddition is a chemical reaction between two organic compounds, a dipolarophile and a 1,3-dipole which combine to form five-membered heterocycles containing multiple stereogenic centers. In our research on 5-Chloroisatin and its derivatives [9-12], we have found it useful to use these compounds as precursors for the synthesis of various heterocyclic systems capable of exhibiting pharmacological properties. For our part, we used 1-propargyl-5-chloro-indole-2, 3-dione, which can be employed with dipoles (three azides) in the synthesis of many natural and pharmaceutical products [13]. In addition, it is proposed to theoretically elucidate regioselectivities and stereoselectivities observed experimentally in 1, 3 dipolar cycloaddition reactions using the DFT method[14-17]..

\section{Results and Discussion}

\subsection{Synthesis of dipolarophile 2}

In the framework of synthesizing derivatives associating the 5-Chloroisatin motif, we studied the action of propargyl bromide, with respect to 5-chloroisatin, gives the product: 5chloro-1- (prop-2-ynyl) indoline-2, 3-dione 2 at an ambient temperature solubilized In DMF under the conditions of phase transfer catalysis in the presence of $\mathrm{K}_{2} \mathrm{CO}_{3}$ as base. [18].

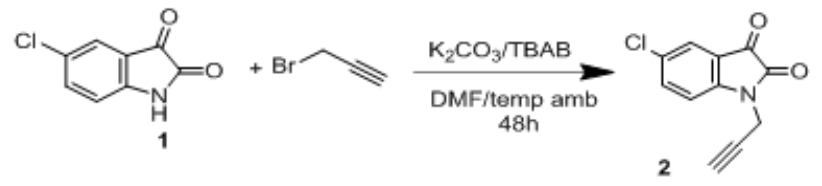

Scheme 1

\subsection{Condensation with azides}

The cycloaddition of Azide-Alcyne without catalyst is developed by Huisgen, makes it possible to obtain a wide variety of five-membered heterocycles in a rapid, reproducible and quantitative manner, via hetero-atomic bonds. The Huisgen reaction itself is an addition between a true alkyne and an azide to form a triazole ring, the conventional conditions of this reaction require high temperatures, long reaction times and lead to a mixture of two disubstituted isomer triazoles 1, 4 and 1.5 [19]. We have not observed, in any case, the cycloaddition on the oxygen carbon double bond.
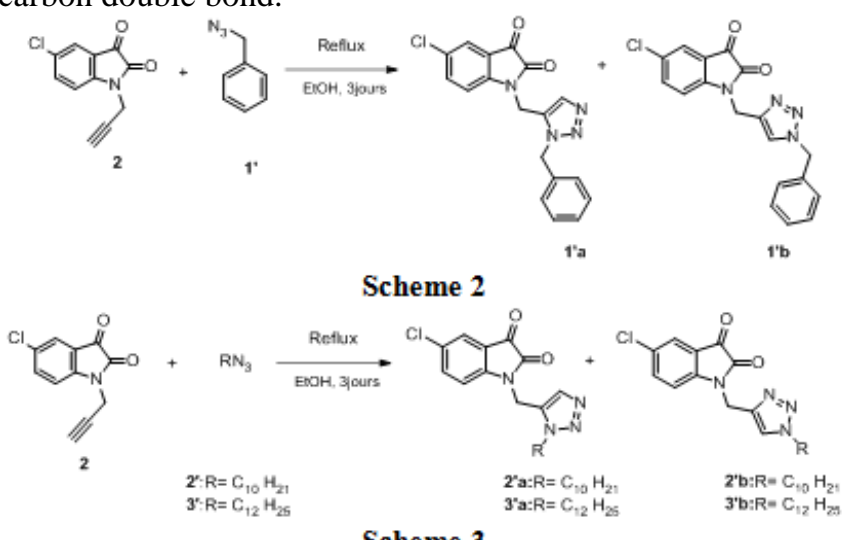

Scheme 3

\section{Theoretical Studies}

\subsection{DFT study of compounds}

The development of the theoretical reactivity indices, mainly those resulting from the conceptual DFT, is based on a theory developed some decades ago that has proved its effectiveness in explaining or predicting the reactivity of molecular systems. The importance of the highest occupied molecular orbital (HOMO) and the lowest unoccupied molecular orbital (LUMO) in chemical reactions was introduced and explained by Fukui [20, 21]. Density functional theory (DFT) is currently a true source of chemical concepts [22], such as electron chemical potential, electronegativity, hardness, softness, electrophilicity, dipole

Volume 6 Issue 7, July 2017 www.ijsr.net 


\section{International Journal of Science and Research (IJSR) \\ ISSN (Online): 2319-7064 \\ Index Copernicus Value (2015): 78.96 | Impact Factor (2015): 6.391}

moment... etc, to understand, describe and identify the most reactive sites of dipolarophile $\mathbf{2}$ and dipoles 1', 2', 3'[23].

Table1: Differences energy possible between HOMO/LUMO combinations of azides and dipolarophile

\begin{tabular}{|c|c|c|}
\cline { 2 - 3 } \multicolumn{1}{c|}{} & $\begin{array}{c}\text { | HOMO azide - LUMO } \\
\text { alcyne }\end{array}$ & $\begin{array}{c}\text { |HOMO alcyne -LUMO } \\
\text { azide }\end{array}$ \\
\hline $\mathbf{1}$ & 3,771 & 5,645 \\
\hline $\mathbf{2}^{\prime}$ & 3,522 & 5,702 \\
\hline $\mathbf{3}^{\prime}$ & 3,564 & 5,680 \\
\hline
\end{tabular}

These results suggest that the reactions between the azides and the dipolarophile are controlled by HOMO azide LUMO dipolarophile.

It should be noted that this reaction was analyzed using the local and global indexes defined in the context of the functional density theory [24].

In Tables 2, 3 and 4 , electron affinity $\left(E A=-E_{L U M O}\right)$, ionization potential $\left(I P=-E_{\text {HOMO }}\right)$, electronegativity $(\chi=$ $\left.\frac{I P+E A}{2}\right)$, global hardness $\left(\eta=\frac{I P-E A}{2}\right)$, softness $\left(S=\frac{1}{\eta}\right)$, the overall electrophicity $(\omega)$, the electrophilicity condensed functions of Fukui $f_{k}$, the relative electrophilicity indices $\left(S_{k}^{+} / S_{k}^{-}\right)$and nucleophilicity indices $\left(S_{k}^{-} / S^{+}{ }_{k}\right)$ for dipolarophile $\mathbf{2}$ and dipoles 1', 2', 3' were presented

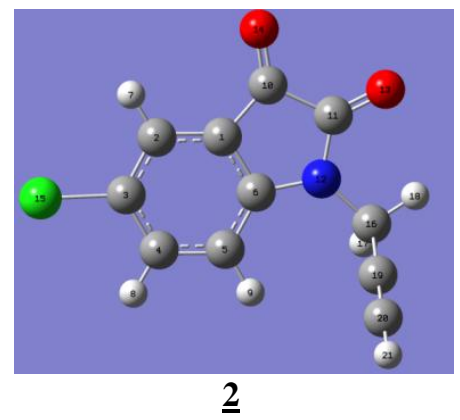

Figure 1: Optimized geometry of the dipolarophile 2
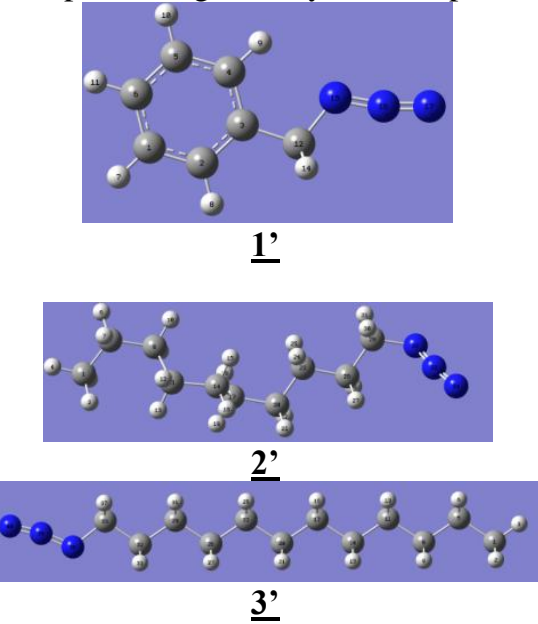

Figure 2: Optimized geometries of dipoles 1', 2', 3'

Table 2: ionization potential $(P I)$, Electronic affinities $(E A)$ and Kohn-Sham orbital values for HOMO and LUMO

\begin{tabular}{|c|c|c|c|c|}
\hline Molecules & HOMO & LUMO & $E A$ & $P I$ \\
\hline 2 & $-6,7608$ & $-3,2462$ & 3,2462 & 6,7608 \\
\hline 3 & $-7,0176$ & $-1,1152$ & 1,1152 & 7,0176 \\
\hline 4 & $-6,7684$ & $-1,0587$ & 1,0587 & 6,7684 \\
\hline 5 & $-6,8111$ & $-1,0802$ & 1,0802 & 6,8111 \\
\hline
\end{tabular}

Several recent studies have demonstrated that these parameters are useful and powerful tools for studying nucleophilic and electrophilic reactions for a wide variety of systems [25-29].

In a limited representation of the difference for these indices, $\mu, \eta$ and $S$ can be evaluated from electron affinity $(E A)$ and ionization potential $(P I)$.

Indeed, if one sees the difference of the chemical potential between the dipolarophile 2 and the azides, one can determine the direction of the transfer of charge.

The result $\left(\left(\mu_{1}, 2,3,-\mu_{2}\right)\right.$ (table 3$)$ indicates that the net charge transfer will occur from azide $\left(\mathbf{1}^{\prime}, \mathbf{2}, \mathbf{3}^{\prime}\right)$ to the dipolarophile $\mathbf{2}$ in the case of all the reactions carried out, which implies that the azides act as nucleophiles. The same conclusion is made by considering the values $\omega$ of the overall electrophilicity, the largest value corresponds to the most electrophilic one which implies that the dipolarophile acts as an electrophile.

Table 3: Values in eV of hardness $\eta$, electronic chemical potential $\mu$, the index of electrophilicity $\omega$ and the result $\Delta \mu=$

\begin{tabular}{|c|c|c|c|c|c|c|}
\multicolumn{6}{c}{$\left(\mu_{1}, \mathbf{2}^{\prime}, \mathbf{3},-\mu_{\mathbf{2}}\right)$ of compounds $\mathbf{2}$ and 1', 2', 3'. } \\
\cline { 2 - 7 } \multicolumn{1}{c|}{$\boldsymbol{\chi}$} & $\eta$ & $S$ & $\omega$ & $\mu$ & $\Delta \mu$ \\
\hline$\underline{2}$ & 5,0035 & 1,7572 & 0,5690 & 7,1233 & $-5,0035$ & - \\
\hline$\underline{\underline{1}}$ & 4,0664 & 2,9512 & 0,3388 & 2,8015 & $-4,0664$ & 0,9371 \\
\hline$\underline{2^{\prime}}$ & 3,9136 & 2,8548 & 0,3502 & 2,6825 & $-3,9136$ & 1,0899 \\
\hline$\underline{\mathbf{3}^{\prime}}$ & 3,9457 & 2,8654 & 0,3489 & 2,7166 & $-3,9457$ & 1,0578 \\
\hline
\end{tabular}

This reciprocal action corresponds to a reaction in which the electrophile-the dipolarophile reacts with the azide-the nucleophile. From a local point of view, the relative electrophilicity indexes $\left(S^{+}{ }_{k} / S_{k}^{-}\right)$and nucleophilicity $\left(S_{k}^{-} / S^{+}{ }_{k}\right)$ describe the electrophilicity of an atomic center compared with its own nucleophilicity [30-33]. The site with the largest ratio $\left(S_{k}^{+} / S_{k}^{-}\right)$is the most likely site for a nucleophilic attack and the one with the largest $\left(S_{k} / S^{+}{ }_{k}\right)$, most likely to interact with an electrophile.

Table 4: Relative indices of electrophilicity, nucleophilicity (in $\mathrm{eV}$ ) and values of the condensed function of Fukui $\mathrm{f}_{\mathrm{k}}$ for the junction atoms for $\mathbf{2}$ and 1', 2', 3'.

\begin{tabular}{|l|c|c|c|c|c|}
\cline { 2 - 6 } \multicolumn{1}{c|}{} & Atomes & $f^{+}{ }_{k}$ & $f_{k}$ & $S^{+}{ }_{k} / S_{k}^{-}$ & $S_{k}^{-} / S^{+}{ }_{k}$ \\
\hline \multirow{2}{*}{$\underline{2}$} & $\mathrm{C} 19$ & -0, & -0, & & \\
\cline { 2 - 6 } & $\mathrm{C} 20$ & 0,111 & 032 & 1,439 & 0,694 \\
\hline \multirow{2}{*}{$\underline{1}$} & $\mathrm{~N} 15$ & 0,073 & 0,182 & 1,091 & 0,915 \\
\cline { 2 - 6 } & $\mathrm{N} 17$ & 0,712 & 0,749 & 0,401 & 2,493 \\
\hline \multirow{2}{*}{$\underline{\underline{2}}$} & $\mathrm{~N} 32$ & 0,162 & 0,180 & 0,899 & 1,051 \\
\cline { 2 - 6 } & $\mathrm{N} 34$ & 0,200 & 0,228 & 0,875 & 1,111 \\
\hline \multirow{2}{*}{$\underline{3} \underline{\underline{y y y y y}}$} & $\mathrm{~N} 38$ & 0,149 & 0,162 & 0,921 & 1,084 \\
\cline { 2 - 6 } & $\mathrm{N} 40$ & 0,162 & 0,230 & 0,702 & 1,423 \\
\hline
\end{tabular}

The carbon atom of the dipolarophile (C19) has a better $S^{+}{ }_{k} / S_{k}^{-}$ratio and can therefore be considered as the site most susceptible to nucleophilic attack.

If we consider the azides, the $S_{k}^{-} / S^{+}{ }_{k}$ ratios (Table 4) suggest that the N15, N34 and N40 nitrogens are the most reactive nucleophilic sites, which is in agreement with the experimental results. It would be important to consider that the reaction is not necessarily controlled orbitally.

\section{Volume 6 Issue 7, July 2017 www.ijsr.net}




\section{International Journal of Science and Research (IJSR) \\ ISSN (Online): 2319-7064}

Index Copernicus Value (2015): 78.96 | Impact Factor (2015): 6.391

The theoretical studies have been carried out and the natural loads have been calculated in order to understand the regiochemistry of the cycloadditions of the azides with the dipolarophiles [34].

During this reaction, the majority isomers formed were explained by the reaction between the most negative side of the 1,3-dipole with the least negatively charged carbon of the triple bond. The theoretical study is in perfect agreement with the regiochemistry obtained during the cycloaddition reaction

\subsection{Stability study of cycloadducts 1'a-3'a and 1'b-3'b:}

The next step is to study the stability of compounds 1'a-3'a and 1 'b-3'b according to their energies, using the quantum chemistry calculation DFT / B3LYP / 6-31G. The following figures 3, 4 and 5 show their optimized structures.

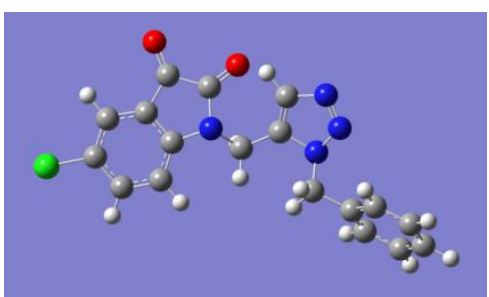

Compound 1'a

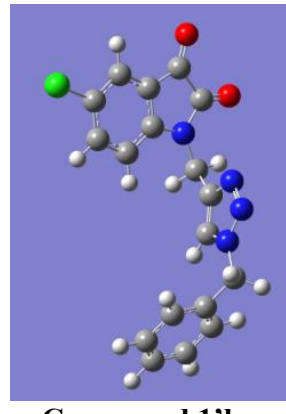

Compound 1'b
Figure 3: The obtained molecular structures 1'a and 1'b by DFT / B3LYP / 6-31G

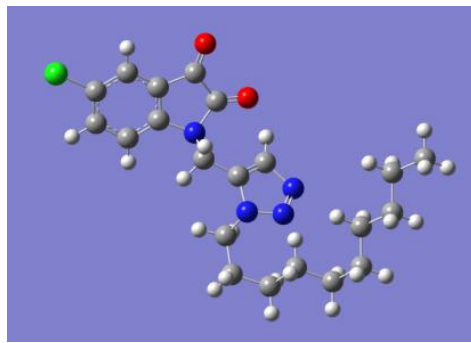

Compound 2'a

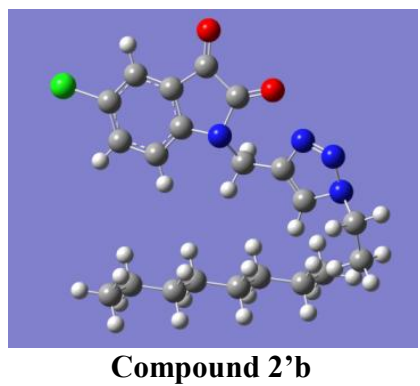

Figure 4: The obtained molecular structures 2'a and 2'b by DFT / B3LYP / 6-31G

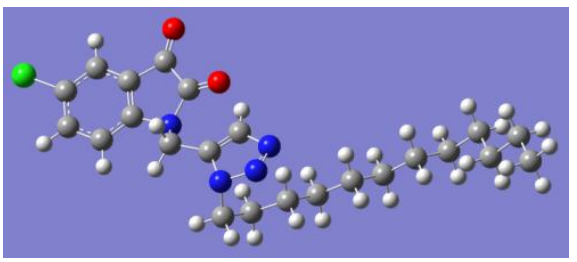

Compound 3'a

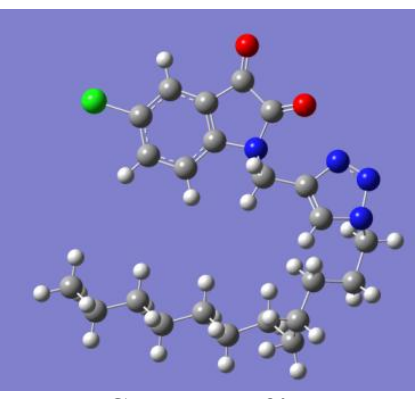

Compound 3'b

Figure 5: The obtained molecular structures 3'a and 3'b by DFT / B3LYP / 6-31G

It can be seen that the regioisomer obtained experimentally 1 'b is more stable than the isomer 1'a of an energy gap of $5.96 \mathrm{Kcal} / \mathrm{mol}$, so the same thing is observed for the other regioisomers, it is seen that the regioisomer $2^{\prime} b$ is more stable than the isomer 2'a of an energy gap of $5.83 \mathrm{Kcal} / \mathrm{mol}$ and finally it is clearly identified that the regioisomer 3 'b is more stable than the isomer 3'a of an energy gap of 5.15 $\mathrm{Kcal} / \mathrm{mol}$.

\section{Conclusion}

From the obtained results and by using the DFT calculations, the cycloaddition reactions between the dipolarophile and the three azides allowed us to confirm the results obtained experimentally is investigated that leads to the following conclusions:

The results of calculation by the DFT method with the functional B3LYP and the standard base $6-31 \mathrm{G}$, by comparing the energies of each regioisomer in the case of the three reactions show that isomer 1 'b is more stable than isomer 1'a, whereas isomer 2'b is more stable than isomer 2'a and isomer 3'b more stable than isomer 3'a. Thus the difference in the chemical potential between the azides (1', $\left.\mathbf{2}^{\prime}, \mathbf{3}^{\prime}\right)$ and the dipolarophile $\mathbf{2}$ made it possible to determine the evolution of the charge transfer which will occur from the dipole $\left(\mathbf{1}^{\prime}, \mathbf{2}^{\prime}, \mathbf{3}^{\prime}\right)$ acting as a nucleophile towards the dipolarophile 2 which behaves like an electrophile.

\section{Experimental part}

\subsection{Generality}

Thin layer chromatography (TLC) was carried out on aluminum-coated silica gel coated Merck plates revealed by a U.V. The column chromatographies were carried out on 60 Merck silica gel (230-400 mesh). The melting points were made using a capillary apparatus: fine control Electrothermal capillary, and also by the kofler bench apparatus. The nuclear magnetic resonance spectra of the ${ }^{1} \mathrm{H}$ proton and ${ }^{13} \mathrm{C}$ carbon are carried out on a Brucker AC 300. Chemical shifts are expressed in parts per million (ppm) relative to tetramethylsilane (TMS), used as an internal reference. The spectra are recorded in deuterated chloroform $\mathrm{CDCl}_{3}$ or deuterated DMSO. 


\section{International Journal of Science and Research (IJSR) \\ ISSN (Online): 2319-7064}

Index Copernicus Value (2015): 78.96 | Impact Factor (2015): 6.391

\subsection{Synthesis of dipolarophile:}

\subsubsection{General method for obtaining the dipolarophile:}

$0.2 \mathrm{~g}(1.1 \mathrm{mmol})$ of 5-chloro- $1 H$-indole-2, 3-dione, $(0.23 \mathrm{~g}$, $1.16 \mathrm{mmol}$ ) of potassium carbonate in $15 \mathrm{ml}$ of $\mathrm{N}, \mathrm{N}-$ dimethylformamide, $(0.035 \mathrm{~g}, 0.10 \mathrm{mmol})$ of BTBA are introduced two-necked flask under magnetic stirring, 1.2 equivalents of 3-bromoprop-1-yne are added slowly, the mixture is left at room temperature for 48 hours. During this period, the progress of the reaction is monitored by TLC (thin layer chromatography). After the reaction is complete, the salts are removed by filtration, the solvent (DMF) is evaporated under reduced pressure and the residue taken up in dichloromethane to precipitate the remaining salts. After a second filtration and evaporation of the solvent, the pure product is obtained after recrystallization from ethanol.

2:5-chloro-1-(prop-2-ynyl)indoline-2, 3-dione: yield: $88 \%$; mp: $166-170^{\circ} \mathrm{C} ; \mathrm{R}_{\mathrm{f}}=0.78,{ }^{1} \mathrm{H}$ NMR $\left(\mathrm{CDCl}_{3}\right) \delta \mathrm{ppm}$ 7.57-7.62 (m, 2H, $\left.\mathrm{H}_{\mathrm{Ar}}\right) ; 7.12\left(\mathrm{~d}, \mathrm{H}, \mathrm{H}_{\mathrm{Ar}},{ }^{3} \mathrm{~J}_{\mathrm{H}-\mathrm{H}}=6 \mathrm{~Hz}\right) ; 4.54$ $\left(\mathrm{s}, 2 \mathrm{H}, \mathrm{CH}_{2}\right) ; 2.34\left(\mathrm{t}, \mathrm{H},{ }^{4} \mathrm{~J}_{\mathrm{H}-\mathrm{H}}=3 \mathrm{~Hz}\right),{ }^{13} \mathrm{C} \mathrm{NMR}\left(\mathrm{CDCl}_{3}\right)$ Sppm :181.55 $(\mathrm{C}=\mathrm{O}) ; 156.60(\mathrm{~N}-\mathrm{C}=\mathrm{O}) ; 147.87,130.07$, $118.50 \quad(\mathrm{Cq}) ; \quad 137.80, \quad 125.24, \quad 112.75 \quad\left(\mathrm{CH}_{\mathrm{Ar}}\right)$ ;73.72(C $\equiv \mathrm{C}) ; 71.21(\mathrm{CH}) ; 29.59\left(\mathrm{CH}_{2}\right)$

\subsection{General method for obtaining 1, 2, 3-triazoles:}

$0.2 \mathrm{~g}$ of 5-chloro-1- (prop-2-ynyl) -indoline-2, 3-dione and 1.2 equivalent of azide (benzyl azide...) in ethanol are dissolved in a flask. The mixture is stirred under reflux for 3 days, the reaction is followed by TLC; the reaction crude is purified by chromatography on a silica gel column (ethyl acetate / Hexane (5/1)). The reaction leads to the formation of two separable regioisomers.

1'a:1-((3-benzyl-3H-1, 2, 3-triazol-4-yl)methyl)-5chloroindoline-2, 3-dione:

Yield : 20\%; mp:140-145 ${ }^{\circ} \mathrm{C} ; \mathrm{R}_{\mathrm{f}}=0.55 .{ }^{1} \mathrm{H}$ NMR $\left(\mathrm{CDCl}_{3}\right.$. $300 \mathrm{MHz}) \delta$ ppm 7.34-7.37(m, 2H, $\left.\mathrm{H}_{\mathrm{Ar}}\right) ; 7.31\left(\mathrm{~d}, \mathrm{H}, \mathrm{H}_{\mathrm{Ar}},{ }^{4} \mathrm{~J}_{\mathrm{H}-\mathrm{H}}\right.$ $=3 \mathrm{~Hz}) ; 7.11\left(\mathrm{~d}, 2 \mathrm{H}, \mathrm{H}_{\mathrm{Ar},}{ }^{4} \mathrm{~J}_{\mathrm{H}-\mathrm{H}}=3 \mathrm{~Hz}\right) ; 7.04-7.07\left(\mathrm{~m}, 2 \mathrm{H}, \mathrm{H}_{\mathrm{Ar}}\right)$; $6.76\left(\mathrm{~d}, 2 \mathrm{H}, \mathrm{H}_{\mathrm{Ar},}{ }^{4} \mathrm{~J}_{\mathrm{H}-\mathrm{H}}=3 \mathrm{~Hz}\right) ; 6.51\left(\mathrm{~d}, \mathrm{H}, \mathrm{H}_{\mathrm{Ar},}{ }^{4} \mathrm{~J}_{\mathrm{H}-\mathrm{H}}=3 \mathrm{~Hz}\right)$; $5.27(\mathrm{~s}, 2 \mathrm{H}, \mathrm{CH} 2) ; 4.94\left(\mathrm{~s}, 2 \mathrm{H}, \mathrm{CH}_{2}\right) .{ }^{13} \mathrm{C} \mathrm{NMR}\left(\mathrm{CDCl}_{3}\right.$;

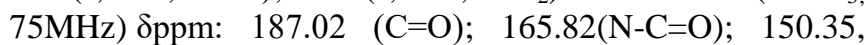
143.77, 136.14, 133.17, 118.33(Cq); 131.25, 129.99, 128.19, $126.18,123.63\left(\mathrm{CH}_{\mathrm{Ar}}\right) 131.67(\mathrm{CH}) ; 57.06,44.34\left(\mathrm{CH}_{2}\right)$.

1'b:1-((1-benzyl-1H-1, 2, 3-triazol-4-yl)methyl)-5chloroindoline-2, 3-dione:

Yield : 73\%; mp:140-145 ${ }^{\circ} \mathrm{C} ; \mathrm{R}_{\mathrm{f}}=0.55 .{ }^{1} \mathrm{H} \mathrm{NMR}\left(\mathrm{CDCl}_{3}\right.$; $300 \mathrm{MHz}) \delta$ ppm 7.32-7.33 (m, 2H, $\left.\mathrm{H}_{\mathrm{Ar}}\right) ; 7.27\left(\mathrm{~d}, \mathrm{H}, \mathrm{H}_{\mathrm{Ar}},{ }^{4} \mathrm{~J}_{\mathrm{H}-}\right.$ $\mathrm{H}=3 \mathrm{~Hz}) ; 7.07\left(\mathrm{~d}, 2 \mathrm{H}, \mathrm{H}_{\mathrm{Ar},}{ }^{4} \mathrm{~J}_{\mathrm{H}-\mathrm{H}}=3 \mathrm{~Hz}\right) ; 7.00-7.03(\mathrm{~m}, 1 \mathrm{H}$, $\mathrm{CH}) ; 6.74\left(\mathrm{~d}, 2 \mathrm{H}, \mathrm{H}_{\mathrm{Ar},}{ }^{4} \mathrm{~J}_{\mathrm{H}-\mathrm{H}}=3 \mathrm{~Hz}\right) ; 6.47\left(\mathrm{~m}, \mathrm{H}, \mathrm{H}_{\mathrm{Ar}}\right) ; 5.23(\mathrm{~s}$, $\left.2 \mathrm{H}, \mathrm{CH}_{2}\right) ; 4$ 4. $90 \quad\left(\mathrm{~s}, 2 \mathrm{H}, \mathrm{CH}_{2}\right) .{ }^{13} \mathrm{C} \mathrm{NMR}\left(\mathrm{CDCl}_{3}\right.$;

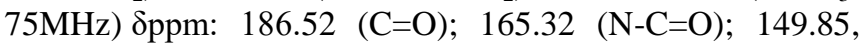
143.28, 135.64, 130.55, $117.83(\mathrm{Cq})$; 132.67, 131.17, 129.49, $127.69,123.13\left(\mathrm{CH}_{\mathrm{Ar}}\right) 125.68(\mathrm{CH}) ; 56.56,43.84\left(\mathrm{CH}_{2}\right)$

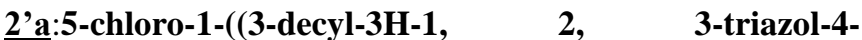
yl)methyl)indoline-2, 3-dione:

Yield: $19 \%$; mp: $130-135^{\circ} \mathrm{C} ; \mathrm{R}_{\mathrm{f}}=0.55 .{ }^{1} \mathrm{H}$ NMR $\left(\mathrm{CDCl}_{3}\right.$; $300 \mathrm{MHz}) \delta$ ppm $7.56\left(\mathrm{~m}, \mathrm{H}, \mathrm{H}_{\mathrm{Ar}}\right) ; 7.53-7.54\left(\mathrm{~m}, 2 \mathrm{H}, \mathrm{H}_{\mathrm{Ar}}\right)$; $7.33\left(\mathrm{~d}, \mathrm{H}, \mathrm{H}_{\mathrm{Ar},}{ }^{4} \mathrm{~J}_{\mathrm{H}-\mathrm{H}}=3 \mathrm{~Hz}\right) ; 4.99\left(\mathrm{~s}, 2 \mathrm{H}, \mathrm{CH}_{2}\right) ; 4.29(\mathrm{t}, 2 \mathrm{H}$, $\left.\mathrm{CH}_{2},{ }^{3} \mathrm{~J}_{\mathrm{H}-\mathrm{H}}=9 \mathrm{~Hz}\right) ; 1.82-1.87\left(\mathrm{~m}, 2 \mathrm{H}, \mathrm{CH}_{2}\right) ; 1.22(\mathrm{~m}, 14 \mathrm{H}$, $\left.\mathrm{CH}_{2}\right), 0.86\left(\mathrm{t}, 3 \mathrm{H}, \mathrm{CH}_{3},{ }^{3} \mathrm{~J}_{\mathrm{H}-\mathrm{H}}=6 \mathrm{~Hz}\right) .{ }^{13} \mathrm{C} \mathrm{NMR}\left(\mathrm{CDCl}_{3}\right.$;

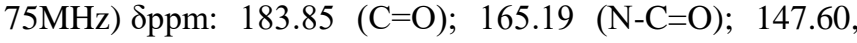
$144.20,130.63,111.98(\mathrm{Cq}) ; 135.72,130.42,123.43\left(\mathrm{CH}_{\mathrm{Ar}}\right)$ $133.82(\mathrm{CH}) ; 53.67,45.41,33.11,29.93,28.87,27.39,23.14$ $\left(\mathrm{CH}_{2}\right) ; 16.78\left(\mathrm{CH}_{3}\right)$.

\section{2'b:5-chloro-1-((1-decyl-1H-1, 2, 3-triazol-4}

yl)methyl)indoline-2, 3-dione:

Yield: $71 \%$; mp: $130-135^{\circ} \mathrm{C} ; \mathrm{R}_{\mathrm{f}}=0.55 .{ }^{1} \mathrm{H}$ NMR $\left(\mathrm{CDCl}_{3}\right.$; $300 \mathrm{MHz}) \delta$ ppm $7.53\left(\mathrm{~m}, \mathrm{H}, \mathrm{H}_{\mathrm{Ar}}\right) ; 7.49-7.51\left(\mathrm{~m}, 2 \mathrm{H}, \mathrm{H}_{\mathrm{Ar}}\right)$; $7.28\left(\mathrm{~d}, \mathrm{H}, \mathrm{H}_{\mathrm{Ar},}{ }^{4} \mathrm{~J}_{\mathrm{H}-\mathrm{H}}=3 \mathrm{~Hz}\right) ; 4.96\left(\mathrm{~m}, 2 \mathrm{H}, \mathrm{CH}_{2}\right) ; 4.26(\mathrm{t}, 2 \mathrm{H}$ $\left.\mathrm{CH}_{2},{ }^{3} \mathrm{~J}_{\mathrm{H}-\mathrm{H}}=9 \mathrm{~Hz}\right) ; 1.80-1.84\left(\mathrm{~m}, 2 \mathrm{H}, \mathrm{CH}_{2}\right) ; 1.19(\mathrm{~m}, 14 \mathrm{H}$, $\left.\mathrm{CH}_{2}\right), 0.81\left(\mathrm{t}, 3 \mathrm{H}, \mathrm{CH}_{3},{ }^{3} \mathrm{~J}_{\mathrm{H}-\mathrm{H}}=6 \mathrm{~Hz}\right) .{ }^{13} \mathrm{C} \mathrm{NMR}\left(\mathrm{CDCl}_{3}\right.$;

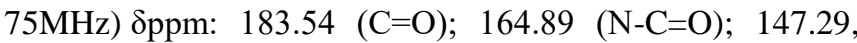
$143.90,130.33,111.67(\mathrm{Cq}) ; 135.42,130.12,124.82\left(\mathrm{CH}_{\mathrm{Ar}}\right)$ $123.12(\mathrm{CH}) ; 53.37,45.10,32.81,29.62,28.57,27.08,22.84$ $\left(\mathrm{CH}_{2}\right) 16.48\left(\mathrm{CH}_{3}\right)$

3'a:5-chloro-1-((3-dodecyl-3H-1, $\quad 2, \quad$ 3-triazol-4yl)methyl)indoline-2, 3-dione:

Yield: $18 \%$; mp: $135-138^{\circ} \mathrm{C} ; \mathrm{R}_{\mathrm{f}}=0.55 .{ }^{1} \mathrm{H}$ NMR $\left(\mathrm{CDCl}_{3}\right.$; $300 \mathrm{MHz}) \delta \mathrm{ppm} 7.56\left(\mathrm{~m}, \mathrm{H}, \mathrm{H}_{\mathrm{Ar}}\right) ; 7.51-7.53\left(\mathrm{~m}, 2 \mathrm{H}, \mathrm{H}_{\mathrm{Ar}}\right)$; $7.30\left(\mathrm{~d}, \mathrm{H}, \mathrm{H}_{\mathrm{Ar},}{ }^{4} \mathrm{~J}_{\mathrm{H}-\mathrm{H}}=3 \mathrm{~Hz}\right) ; 4.98\left(\mathrm{~s}, 2 \mathrm{H}, \mathrm{CH}_{2}\right) ; 4.30(\mathrm{t}, 2 \mathrm{H}$, $\left.\mathrm{CH}_{2},{ }^{4} \mathrm{~J}_{\mathrm{H}-\mathrm{H}}=3 \mathrm{~Hz}\right) ; 1.83\left(\mathrm{t}, 2 \mathrm{H}, \mathrm{CH}_{2},{ }^{3} \mathrm{~J}_{\mathrm{H}-\mathrm{H}}=9 \mathrm{~Hz}\right) ; 1.21(\mathrm{~m}$, $\left.10 \mathrm{H}, \mathrm{CH}_{2}\right) ; 0.85$ (t, $\left.3 \mathrm{H}, \mathrm{CH}_{3},{ }^{3} \mathrm{~J}_{\mathrm{H}-\mathrm{H}}=6 \mathrm{~Hz}\right) .{ }^{13} \mathrm{C} \mathrm{NMR}\left(\mathrm{CDCl}_{3}\right.$;

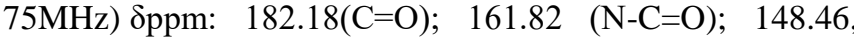
$144.22,132.35,114.97(\mathrm{Cq}) ; 135.53,131.51,123.24\left(\mathrm{CH}_{\mathrm{Ar}}\right)$; $130.57(\mathrm{CH}) ; 52.43,45.85,38.43,30.38,30.16,29.11,28.26$, $23.38\left(\mathrm{CH}_{2}\right) ; 18.50\left(\mathrm{CH}_{3}\right)$.

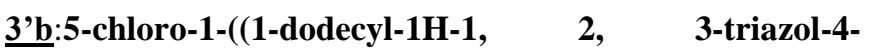
yl)methyl)indoline-2, 3-dione:

Yield: $70 \%$; mp: $135-138^{\circ} \mathrm{C} ; \mathrm{R}_{\mathrm{f}}=0.55 .{ }^{1} \mathrm{H}$ NMR $\left(\mathrm{CDCl}_{3}\right.$ $300 \mathrm{MHz}) \delta \mathrm{ppm} 7.52\left(\mathrm{~m}, \mathrm{H}, \mathrm{H}_{\mathrm{Ar}}\right) ; 7.47-7.50\left(\mathrm{~m}, 2 \mathrm{H}, \mathrm{H}_{\mathrm{Ar}}\right)$; 7.28(d, H, H $\left.{ }_{\mathrm{Ar},}^{4} \mathrm{~J}_{\mathrm{H}-\mathrm{H}}=3 \mathrm{~Hz}\right) ; 4.94\left(\mathrm{~s}, 2 \mathrm{H}, \mathrm{CH}_{2}\right) ; 4.24(\mathrm{t}, 2 \mathrm{H}$, $\left.\mathrm{CH}_{2},{ }^{4} \mathrm{~J}_{\mathrm{H}-\mathrm{H}}=3 \mathrm{~Hz}\right) ; 1.80\left(\mathrm{t}, 2 \mathrm{H}, \mathrm{CH}_{2},{ }^{3} \mathrm{~J}_{\mathrm{H}-\mathrm{H}}=9 \mathrm{~Hz}\right) ; 1.17(\mathrm{~m}$ $\left.18 \mathrm{H}, \mathrm{CH}_{2}\right) ; 0.79\left(\mathrm{t}, 3 \mathrm{H}, \mathrm{CH}_{3},{ }^{3} \mathrm{~J}_{\mathrm{H}-\mathrm{H}}=6 \mathrm{~Hz}\right) .{ }^{13} \mathrm{C} \mathrm{NMR}\left(\mathrm{CDCl}_{3}\right.$;

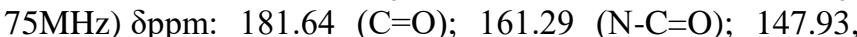
143.69, $114.44(\mathrm{Cq}) ; 135.00,130.97,122.71\left(\mathrm{CH}_{\mathrm{Ar}}\right) ; 123.34$ (CH); 51.89, 45.32, 37.90, 29.84, 29.63, 28.58, 27.72, 22.85 $\left(\mathrm{CH}_{2}\right) ; 17.97\left(\mathrm{CH}_{3}\right)$

\section{References}

[1] Z. Tribak, R. Ghibate, M.K. Skalli, Y. Kandri Rodi, D. Mrani, A. Aouniti, B. Hammouti, O. Senhaji, Synthesis and Characterization of a New Cationic Surfactant Derived from 5-Chloro-1H-indole-2, 3-dione In Aqueous Systems, Int. J. Eng Res Appl.. 7 (4)(2017) 04-08

[2] Z. Tribak, O. El Amin, M.K. Skalli, O. Senhaji, Y. Kandri. Rodi, M. Houssaini. Iraqui, N-alkylation methods, Characterization and Evaluation of antibacterial activity of some Novel 5-Chloroisatin Derivatives Int. J. Eng Res Appl.. 7(6)(2017) 21-24

[3] Z. Tribak, O. El Amin, M.K. Skalli, O. Senhaji, Y. Kandri. Rodi, M. Houssaini. Iraqui, Synthesis, Characterization, and Antibacterial Activity of Some Novel 5-Chloroisatin Derivatives Int. J. Eng Res Appl. 7(6)(2017) 66-70

[4] Z. Tribak, A. Haoudi, M.K. Skalli, Y. Kandri Rodi, M. El Azzouzi, A. Aouniti, B. Hammouti, O. Senhaji, 5 Chloro-1H-indole-2, 3-dione derivative as corrosion inhibitor for mild steel in $1 \mathrm{M} \mathrm{H}_{3} \mathrm{PO}_{4}$ : weight loss, 


\section{International Journal of Science and Research (IJSR) \\ ISSN (Online): 2319-7064 \\ Index Copernicus Value (2015): 78.96 | Impact Factor (2015): 6.391}

electrochemical and SEM studies.J. Mater. Environ. Sci. 8 (1) (2017) 298-309.

[5] Z. Tribak, Y. Kandri Rodi, H. Elmsellem, I. AbdelRahman, A. Haoudi, M. K. Skalli, Y. Kadmi, B. Hammouti, M. Ali Shariati, E. M. Essassi, 5-chloro-1octylindoline-2, 3-dione as a new corrosion inhibitor for mild steel in hydrochloric acid solution J. Mater. Environ. Sci. 8 (3) (2017) 1116-1127.

[6] Zineb. Tribak, Youssef Kandri Rodi, Amal Haoudi, El Mokhtar Essassi, Frédéric Capet et Hafid Zouihri, 1Benzyl-5-chloroindoline-2, 3-dione IUCrData 1(6) (2016) 1, x160854.

[7] .N.Kumar Kaushik , N Kaushik, P Attri, N Kumar, C Hyeok Kim, A Kumar Verma' E Ha Choi. Biomedical Importance of Indoles Molecules 18(6) (2013) 6620

[8] M. Krug, A. Hilgeroth. Recent advances in the development of multi-kinase inhibitors. Mini-Rev. Med. Chem. 8 (2008) 1312.

[9] Z. Tribak, A. Haoudi, Y. Kandri Rodi, H. Elmsellem, M. K. Skalli, Y. Ouzidan, A. Mazzah, E.M. Essassi, Synthesis and reactivity of new heterocyclic systems derived from 5-chloro-1H-indole-2, 3-dione. Mor. J. Chem. 4(4) (2016) 1157-1163.

[10] I. C. Alaoui, Y. K. Rodi, A. Keita, S. Sabir, M.K. Skalli, E.M. El Hadrami, E. M. Essassi, synthesis of new heterocyclic systems by 1, 3-dipolar cycloaddition from the 1, 5-benzodiazepine-2, 4-dione Phys. Chem News. 39 (2008) 98

[11] E.E. Ebenso, D.A. Isabirye, N.O. Eddy, Adsorption and Quantum Chemical Studies on the Inhibition Potentials of Some Thiosemicarbazides for the Corrosion of Mild Steel in Acidic Medium Int. J. Mol. Sci., 11 (2010) 2473-2498.

[12] A. Rauk, Orbital Interaction Theory of Organic Chemistry, Wiley-Interscience, New York, (2001)1360

[13] Zineb. Tribak, Youssef Kandri Rodi, Amal Haoudi, El Mokhtar Essassi, Frédéric Capet et Hafid Zouihri, 1(12-Bromododecyl)-5-chloroindoline-2, 3-dione IUCrData 1(6) (2016). 1, x160971

[14] P. Geerlings, F. De Proft, W. Langenaeker, Conceptual density functional theory.Chem. Rev. 103(2003) 1793.

[15] O. Senhaji 1, R. Taouil, M. K. Skalli, M. Bouachrine, B. Hammouti, M. Hamidi, S.S. Al-Deyab Experimental and Theoretical Study for Corrosion Inhibition in Normal Hydrochloric Acid Solution by Some New Phophonated Compounds, Int. J. Electrochem. Sci., 6 (2011) 6290.

[16] H. C. Kolb, M. G. Finn, K. R. Sharpless, Click Chemistry: Diverse Chemical Function from a Few Good Reactions. Angew. Chem. Int.Ed., 40 (2001) 2004.

[17] S. Brase, C. Gil, K. Knepper, V. Zimmermann, Organic azides: an exploding diversity of a unique class of compounds. Angew. Chem. Int. Ed., 44(2005) 5188.

[18] Z. Tribak, Y. Kandri Rodi, A. Haoudi, M.K. Skalli, A. Mazzah, M. Akhazzane, E.M. Essassi. cycloaddition 1, 3-dipolaire des dérives de la 5-chloro- $1 h$-indole-2, 3 dione: vers de nouvelles isoxazolines et spirodioxazolines J.Mar. Chim. Heterocycl $16(1)(2016) 58-65$
[19] R. Huisgen in 1, 3-Dipolar Cycloaddilion Chemistry, A. Padwa Ed., Wiley, New York, 1984

[20] P. Hiberty, Introduction à la chimie quantique, Editions de l'école polytechnique de Paris (2004) 203.

[21] K. N. Houk, J. Sims, R. E. Duke, R. W. Strozier, J. K. George, J. Am. Chem. Soc., 95 (1973) 7287.

[22] R. Dardouri , Y. Kandri Rodi , A. Haoudi , A. Mazzah, M.K. Skalli , E.M. Essassi, F. Ouazzani Chahdi J.Mar.Chim.Heterocycl. 11(2012) 52.

[23] Z. Tribak R. Ghibate, M. K. Skalli Y. Kandri Rodi, O. Senhaji, Experimental and Theoretical Study for Corrosion Inhibition in $1 \mathrm{M} \mathrm{HCl}$ Solution by New 5Chloroisatin Derivative Inter J Sci Tech Eng. 3 (2016) 257- 262

[24] J.Weinberg, D. A. Lerner., Theoretical Study of 5HTP. Potential New Drug Resulting from the Complexation of 5-HTP with ATP. Computational Chem, 1(2013) 1.

[25] S. Pal et K. R. S. Chandrakumar, Critical Study of Local Reactivity Descriptors for Weak Interactions: Qualitative and Quantitative Analysis of Adsorption of Molecules in the Zeolite Lattice. J. Am. Chem. Soc. 122 (2000) 4145.

[26] . F. Mendez et J. L. Gazquez; Chemical Reactivity of Enolate Ions: The Local Hard and Soft Acids and Bases Principle Viewpoint. J. Am. Chem. Soc.;116 (1994) 9298.

[27] J. L. Gazquez et F. Mendez; The Hard and Soft Acids and Bases Principle: An Atoms in Molecules Viewpoint, J. Phys. Chem., 98 (1994) 4591.

[28] F. Mendez, J. Tamariz et P. Geerlings; 1, 3-Dipolar Cycloaddition Reactions: A DFT and HSAB Principle Theoretical Model, J. Phys. Chem., (A)102 (1998), 6292.

[29] . L. R. Domingo, M. T. Picher; A DFT study of the Huisgen 1, 3-dipolar cycloaddition between hindered thiocarbonyl ylides and tetracyanoethylene Tetrahedron, 60 (2004) 5053.

[30] S. Kumar S., D. G. Ladha , P.C. Jha, N.C Shah, Theoretical Study of Chloro-N-(4methoxybenzylidene)aniline Derivatives as Corrosion Inhibitors for Zinc in Hydrochloric Acid, Inter $\mathbf{J}$ Corros., (2013), 1-10

[31] S. Xia, M Qiu, L Yu, F Liu, H Zhao, Molecular dynamics and density functional theory study on relationship between structure of imidazoline derivatives and inhibition performance, Corros. Sci., 50 (2008) 2021-2029.

[32] V. Pilepic et S. Ursic; Nucleophilic reactivity of the nitroso group. Fukui function DFT calculations for nitrosobenzene and 2-methyl-2-nitrosopropane. $J$ Molecular. Struct. (Theochem.) , 538 (2001) 41.

[33] G. Al Houari , A. Kerbal, K. Miqueu, J-M. Sotiropoulos, B. Garrigues, T. Benhadda, N. Benlarbi, I. Safir, M. Filali Baba, synthese de nouveaux spiro[(3methyl-3, 4-dihydro)-1(2h)-naphtalenone-2:5'-(3', 4'diaryl-4', 5'-dihydro)-isoxazoles] par la reaction de cycloaddition dipolaire-1, 3 j. mar.chim..heterocycl 7 (2008) 16.

[34] R. Dardouri , Y. Kandri Rodi , A. Haoudi , A. Mazzah , M.K. Skalli , E.M. Essassi, F. Ouazzani Chahdi. Synthèse et modélisation de nouveaux systèmes hétérocycliques obtenus par cycloaddition 1 , 3- 


\section{International Journal of Science and Research (IJSR) \\ ISSN (Online): 2319-7064}

Index Copernicus Value (2015): 78.96 | Impact Factor (2015): 6.391

dipolaire dérivant de la 1, 5-benzodiazépine-2, 4-dione j. mar.chim..heterocycl. 11 (2012) 52.

\section{Author Profile}

Dr. Tribak Zineb (Synthesis, NMR, organic, anti-corrosion activity, DFT, Quantum-chemistry calculations).

Prof. Skalli Mohammed Khalid (Catalysis and Molecular Modeling)

Volume 6 Issue 7, July 2017 www.ijsr.net 